\title{
BRIEF COMMENTS ON THE CONCEPT OF JUDICIAL AUTHORITY JURISDICTION UNDER ARTICLE 6 OF COUNCIL FRAMEWORK DECISION NO. 2002/584/JHA REGARDING THE EUROPEAN ARREST WARRANT
}

\section{PĂTRĂUŞ}

\author{
MIHAELA PĂTRĂUŞ \\ University of Oradea - Faculty of Law \\ Oradea, str. General Magheru, no. 26, Bihor county \\ mihaelapatraus@yahoo.com
}

\section{ABSTRACT:}

Article 6, paragraph 1 of Framework Decision 2002/584/JHA provides that the issuing judicial authority is the judicial authority of the Member State competent to issue a judicial decision in accordance with the law of that State for the purpose of surrender on the basis of the European arrest warrant to another EU Member State.

The Court of Justice in Luxembourg, by its recent case-law, held that the notion of issuing judicial authority does not concern the prosecutor's offices in a Member State which are at risk of being subjected, directly or indirectly, to individual orders or instructions by the executive power in the context of adopting a decision on the issuing of the European arrest warrant.

The effects of this judgment are mandatory for all Member States and require clarification from the Member States affected by the ECJ ruling regarding the nature of the European arrest warrant authority, even a possible intervention by the legislature in these EU Member States, to facilitate the settlement of cases of arrest in full agreement with the principles of mutual recognition and mutual trust of judgments in the European area.

KEY WORDS: judicial cooperation, mutual recognition principle, European arrest warrant, issuing judicial authority, judicial decision

\section{PREMISE}

The European arrest warrant is a judicial decision issued by the competent judicial authority of an EU Member State for arrest and surrender to another Member State of a requested person for the purpose of carrying out a criminal prosecution or trial or for the execution of a custodial sentence or detention. ${ }^{1}$.

This enforceable judicial decision is based on the principle of mutual recognition and trust and is the cornerstone of judicial cooperation with a view to building the European area of freedom, security and justice ${ }^{2}$.

The Framework Decision on the European arrest warrant reflects a philosophy of integration in a common judicial area and is the first legal instrument adopted to ensure concrete recognition of mutual recognition of judgments.

\footnotetext{
${ }^{1}$ See Article 1 of Council Framework Decision 2002/584/JHA of 13 June 2002 on the European arrest warrant and the surrender procedures between Member States, in OJ L 190/1 of 18 July 2002 as amended by Council Framework Decision 2009/299/JHA on the strengthening of the procedural rights of individuals and the promotion of the application of the principle of mutual recognition to decisions given in the absence of the person concerned from the process, publ. in OJ L 81, 27 March 2009, p. 4.

${ }^{2}$ Objective set out in Recital 5 of Decision 2002/584/JHA, p.3.
} 


\section{Mihaela Pătrăuş}

Decisions on the execution of the European arrest warrant must be subject to sufficient controls, which means that a judicial authority in the Member State in which the requested person was arrested will have to make the decision to surrender $i^{3}$.

The European arrest warrant is executed on the basis of the principle of mutual recognition and trust, but also with respect for fundamental human rights and legal principles enshrined in Article 6 of the Treaty on European Union (TEU) ${ }^{4}$ and Articles 5, 6 and 8 of the Convention European Law of Human Rights (ECHR $)^{5}$ and Article 47 of the EU Charter of Fundamental Rights (CDFUE) ${ }^{6}$.

The Framework Decision on the European Arrest Warrant, as it emerges from both the Strasbourg ${ }^{7}$ and Luxembourg case-law, is deficient in the respect for human rights and fundamental freedoms, although there is no risk of human rights violations in judicial cooperation procedures between Member States, because they are party to the ECHR and are required to comply with the provisions of the Union Treaties and the CFSP, the latter having the same legal value as the Treaties.

In a brief review of the legal texts on fundamental human rights, we observe that legal protection under EU law is more extensive than that conferred by the ECHR, since it guarantees the right to a judicial authority, namely to appeal to a judge, we will develop this issue in the following sections.

The Court of Justice of Luxembourg (CJEU) has enshrined this right as a general principle of Union law ${ }^{8}$.

\section{ESTABLISH THE COMPETENT JUDICIAL AUTHORITY TO EXECUTE THE EUROPEAN ARREST WARRANT}

Article 1 paragraph 1 of the Framework Decision provides that the European Arrest Warrant is a "judicial decision", which must be issued by a "judicial authority".

According to the provisions of Article 6 of Framework Decision 2002/584/JHA, "the issuing judicial authority is the judicial authority of the issuing Member State competent to issue a European arrest warrant in accordance with the law of that State" (paragraph 1).

Framework Decision does not explain the notion of "judicial authority. Therefore, the sphere of judicial authorities that can issue European arrest warrants differs from one Member State to another, which is why the issue has been forced by the European courts.

Before analyzing the case-law of the CJEU, a judicial body with jurisdiction over the unitary and autonomous interpretation of Union law in all Member States ${ }^{9}$, it is necessary to make brief reference to how to determine the competent judicial authorities to issue a European arrest.

Criminal procedure acts, which are extremely varied in their subject-matter, are entrusted in the Member States to judicial bodies or to the judiciary, as the case may be.

Generally, the diversity of these organs is a manifestation of the complexity of the criminal process ${ }^{10}$. This variety of judicial bodies, in relation to established competence and the administration of justice in each Member State, has created difficulties in interpreting the notion of judicial authority competent to issue a European arrest warrant. In some EU

\footnotetext{
${ }^{3}$ See Recital 8 of the 2002/584/JHA Decision, p.4.

${ }^{4}$ See I.Gâlea, Treaty of the European Union. Comments and Explanations, Ed. C.H.Beck, Bucharest, 2012, p. 20 et seq.

${ }^{5}$ Rome, 4 November 1950, ratified by Romania through Law no. 30/1994, publ. in Of. J. nr.135 of May 31, 1994.

${ }^{6}$ CDFUE of 7 December 2000, adopted in Strasbourg on 12 December 2007, publ. in OJOE C Series, no.326 of October 26, 2012.

${ }^{7}$ See ECHR, dec. of 21 February 1975, Golder v. United Kingdom, dec. of 4 December 1979, Schiesser v. Switzerland, dec. of 23 October 1990, Huber v. Switzerland, V.Berger, Jurisprudence of the European Court of Justice of the Homme, Sirey, Paris, 5, 1996, p.315 et seq. ; CJEU: dec. of 10 November 2016, Poltorak C-452/16 PPU, EU: C: 2016: 858 paragraphs 33 and 35; dec. of 10 November 2016, Kovalkovas, C-477/16 PPU, EU: C: 2016: 861 paragraphs 34 and 36, etc.

${ }^{8}$ For the first time in C-222/84, Johnston, www.europa.eu.

${ }^{9}$ For details see M. Patraus, European Institutional Law. University Course, Ed. Pro Universitaria, 2018, Bucharest, p.233 and 236-237.

${ }^{10}$ See G.Stefani, G. Levasseur and B.Bouloc, Penal Procedure, 17-e, Ed.Dalloz, Paris, 2000, p.34.
} 


\section{BRIEF COMMENTS ON THE CONCEPT OF JUDICIAL AUTHORITY JURISDICTION \\ UNDER ARTICLE 6 OF COUNCIL FRAMEWORK DECISION NO. 2002/584/JHA \\ REGARDING THE EUROPEAN ARREST WARRANT}

Member States a clear separation between judicial functions ${ }^{11}$ has taken place, with only judges being able to issue European arrest warrants, but in other Member States the nature of the issuing authority is different ${ }^{12}$ for the European arrest warrant.

In the legal doctrine ${ }^{13}$, the right to the intervention of a judge accompanied by the jurisdictional guarantees of the criminal proceedings make this right not to remain at the ideal stage to which any system of law tends, but to become an effective right. The guarantee of intervention of a member of the judicial authority is expressed by recourse to a judge or court $^{14}$.

According to Article 5 of the ECHR para.3 any person arrested or detained as provided in Article 5 para. 1 let. c) ${ }^{15}$ be brought promptly before a judge or other officer authorized by the law to exercise judicial power and shall be entitled to be sued within a reasonable time or released in the course of the proceedings.

Article 5 (3) ECHR refers structurally to two distinct aspects: the first hours after the arrest, when the person concerned is before the administrative judicial authorities or the prosecutor, and the period before the trial eventually before a criminal court ${ }^{16}$.

In the initial phase of deprivation of liberty, the rights of the arrested person have to be protected by a judicial review that is carried out promptly automatically by a judge or other magistrate $^{17}$.

According to the Strasbourg Court, if the arrested person is not brought before a judge or authorized magistrate there is a violation of the Convention ${ }^{18}$.

The magistrate is not to be confused with the judge, but in order for a magistrate to be considered a judge, he must fulfill certain conditions for the person in custody, a guarantee against arbitrariness or unjustified deprivation of liberty ${ }^{19}$. On the one hand, the judge or another authorized magistrate has the duty to obey the accused who must be brought before the judicial authorities, and on the other hand, the judicial authority is obliged to ex officio examine all matters relating to detention, finally taking a final decision on it.

At the same time, the judge or magistrate with jurisdictional powers must enjoy independence in relation to the executive and with the parties and impartiality ${ }^{20}$.

\footnotetext{
${ }^{11}$ For example, in Romania, according to the provisions of Article 88, paragraph 3, letter a-c of Law no. 302/2004, modified by the Law no. 236/2017, republ. in M.Of., Part I, no. 937 / 14.12.2017, the European Arrest Warrant is issued: at the stage of criminal prosecution, by the judge of rights and freedoms appointed by the President of the court to whom the jurisdiction to adjudicate the case; by the President of the Chamber, in the preliminary-order procedure; in the trial phase, by the judge appointed by the President of the first instance; in the execution phase, by the judge appointed by the President of the enforcement court. The provisions of Law no. 302/2004 regarding the international judicial cooperation in criminal matters are in full agreement with the provisions of art. 203 paragraph 3 Criminal procedure code.

${ }^{12}$ At present, in 17 Member States, the prosecutor is the issuing authority for the European arrest warrant. For example: in Austria, the prosecutor is the one issuing the European arrest warrant, but only in the case where the issue was authorized by the court. There are legal provisions in this Member State that allow the Ministry of Justice to instruct prosecutors in concrete cases, but given that it is the court which decides to issue the European arrest warrant, Austria considers that it fully respects the provisions of Article 6 of the Framework Decision 2002/584/JHA. There are Member States where only prosecutors issue a European arrest warrant and can receive instructions from the Ministry of Justice - Germany, Estonia, France, Denmark, Croatia. In other Member States there are certain features: Lithuania can be classified as issuing judicial authority) and Bulgaria, Finland, Greece (as regards warrants issued for the purpose of prosecution), Belgium and Luxembourg (as regards warrants for execution), Latvia and Portugal, Sweden (the prosecutor is independent of the executive), Italy (in - service training judge) criminal prosecution, prosecutors being independent of the executive power).

${ }^{13}$ See S.Guinchard, M.Bandrac, X.Lagarde and M.Douchy, Droit processuel. Droit commun et droit compar du du process, 2-e, Ed.Dalloz, Paris, 2003, p.291-420 apund Gh.Mateuţ, Treaty of criminal procedure. The general part. Volume I, Ed. H. Beck, Bucharest, 2007, p.255.

${ }^{14}$ Gh.Mateuț, op.cit., p.256.

${ }^{15}$ To conduct before a court because that person is suspected of having committed an offense or committing or fleeing after committing them.

${ }^{16}$ See D.Bogdan, Preventive Arrest and Detention in ECHR Case Law, Ed. Hamangiu, Bucharest, 2008, p.109 et seq.

${ }^{17}$ ECHR dec. of May 22, 1984, De Jong, Baljet and Van den Brink v. the Netherlands.

${ }^{18}$ ECHR dec. of March 11, 2008, Varga v. Romania, October 3, 2006, McKay v. The United Kingdom.

${ }^{19}$ ECHR dec. of December 4, 1979, Schiesser v. Switzerland.

${ }^{20}$ ECHR dec. of 28 October 1998 Assenov v. Bulgaria; Article 14 (1) of the International Covenant on Civil and Political Rights; Article 6 (1) of the ECHR.
} 
Article 5 (4) ECHR uses a different notion, the "court", meaning that it is an independent decision-making body in relation to the executive and the parties but also impartially in the trial of the arrest.

Prosecutors are not, in the opinion of the European Court of Justice ${ }^{21}$, independent magistrates and parties since they can not validly control pre-trial detention or detention insofar as they are susceptible to pursuing the arrested or detained person which might alter their impartiality. Therefore, regarding the members of the Prosecutor's Office, there are no objective appearances of the circumstances of the decision to hold, within the meaning of the provisions of Article 5, paragraph 3.

Taking into account that the surrender procedure based on a European Arrest Warrant must be assimilated to extradition ${ }^{22}$, both procedures having the same effect, under Article 5 (1) (f), it is permissible, inter alia, to verify the legal basis of arrest, the detention of a person against whom the European arrest warrant is underway. However, the European arrest warrant must not be confused with preventive arrest $^{23}$. As regards the European arrest warrant, detention must be accompanied by the communication of sufficient information to the person subject to the European arrest warrant and the conditions of arrest on the basis thereof are set out in Articles 2, 6 and 8 of Council Framework Decision 2002/584/JHA.

\section{INTERPRETATIONS OF THE COURT OF JUSTICE OF THE EUROPEAN UNION CONCEPT OF JUDICIAL AUTHORITY ISSUING A EUROPEAN ARREST WARRANT}

Article 19 (3) (b) of the TEU and Article 267 of the Treaty on the Functioning of the European Union (TFEU) regulates the procedure of prior communications, referred to in the doctrine $^{24}$ as "the crown jewelery" a procedural mechanism by which national courts, have engaged in a direct dialogue with the Court of Justice of the European Union (CJEU) on the field and the way in which Union law is applied, being also the main means of modeling the relationship between national and community law systems ${ }^{25}$.

The decisions of the CJEU on the interpretation of primary and secondary law are mandatory not only for the referring court but also for the other courts in the Member States, and national judges are obliged to interpret the provisions of Union law similarly to the Court $^{26}$.

Regarding the European arrest warrant, the Luxembourg Court has, over time, been called upon to give a preliminary ruling on the interpretation of Article 6 (1) of Framework Decision $2002 / 584 / \mathrm{JHA}^{27}$ in several cases $^{28}$, which the referring courts have doubts as to whether the prosecutor at a prosecutor's office in a Member State fulfills the requirement of independence and that of the role in the administration of criminal justice.

The Court has initially ${ }^{29}$ established that the term "judicial authority" is not limited to designating only judges or courts of a Member State, but must even be interpreted broadly, including authorities involved in the administration of criminal justice in the Member States without ministries or police services that are part of the executive power.

\footnotetext{
${ }^{21}$ ECHR, dec. of 4 December 1979 Schiesser v Switzerland and dec. of 23 October 1990, Huber v. Switzerland.

${ }^{22}$ See recital 11 of Decision 2002/584/JHA, p.4.

${ }^{23}$ See M. Patraus, Reflections on Criminal Law Issues, as set forth in Article 5 of the European Convention on Human Rights, in the volume of Studies on ECHR jurisprudence, National Institute of Magistracy, Bucharest, 2003, p.85 et seq.

${ }^{24}$ See P.Craig and G.Burca, European Union Law - comments, jurisprudence and doctrine, 4th Ed. Hamangiu, Bucharest, 2009 , p.576.

${ }^{25}$ Ibidem, p.578.

${ }^{26}$ See M. Patraus, op.cit., p. 336.

${ }^{27}$ See above, ptc. 2

${ }^{28}$ CJUE: dec. of June 29, 2016, Kossowski C-486/14, EU: C: 2016: 483, dec. of 10 November 2016, Poltorak C-452/16 PPU, EU: C: 2016: 858; dec. of 10 November 2016, Ozcelik C-453/16 PPU, EU: C: 2016: 861, dec. of 10 November 2016, Kovalkovas, C-477/16 PPU, EU: C: 2016: 861, dec. of 27 May 2019, OG and PI C-508/18 and 82/19 PPU, EU: C: 2019.

${ }^{29}$ CJUE: dec. of 10 November 2016, Poltorak C-452/16 PPU, EU: C: 2016: 858; dec. of 10 November 2016, Kovalkovas, C477/16 PPU, EU: C: 2016: 861.
} 
BRIEF COMMENTS ON THE CONCEPT OF JUDICIAL AUTHORITY JURISDICTION

UNDER ARTICLE 6 OF COUNCIL FRAMEWORK DECISION NO. 2002/584/JHA

REGARDING THE EUROPEAN ARREST WARRANT

This interpretation is in line with the provisions of Article 82 paragraph 1 (d) TFEU on judicial cooperation in criminal matters, which must be cooperation between the judicial or equivalent authorities of the Member States in matters of prosecution and enforcement of judgments.

Recently, the CJEU has explained the notion of "issuing judicial authority" of the European Arrest Warrant stating that Art. Article 6 (1) of Framework Decision 2002/584/JHA should be interpreted as meaning that this phrase does not concern the prosecutor's offices in a Member State which are at risk of being subjected, directly or indirectly, to an individual instruction by the executive, a minister of justice, when deciding on the issuing of a European arrest warrant ${ }^{30}$.

In the present case, the applications for a preliminary ruling were made in connection with the execution in Ireland of two European arrest warrants issued by the Prosecutor's Office attached to the Regional Court in Lübeck, Germany, for the purpose of prosecuting against OG - a Lithuanian national residing in Ireland, respectively by the Prosecutor's Office in Zwickau, Germany for the purpose of prosecution against PI-Romanian national.

Under Irish law, judicial authority means that the judge, magistrate or any other person authorized by law performs the same or similar tasks as those performed by a court ${ }^{31}$.

Under German law, officials in the Prosecutor's Office have the obligation to observe the official instructions received from their superiors ${ }^{32}$ and the Federal Minister of Justice in their relationship with the Federal Attorney General and the Federal Prosecutors, in relation to all the officers of the Prosecutor's Office in the country concerned, the highest official in the prosecutor's offices attached to the higher regional courts in relation to all the officers of the Prosecutor's Office attached to that court have the power to supervise and to issue instructions $^{33}$.

The Irish court in its reference for a preliminary ruling has stated that, in relation to the provisions of German law, it has serious doubts that the German Prosecutor's Office, which belongs to a hierarchical structure depending on the Minister of Justice, fulfills the requirement of independence in order to be qualified as a judicial authority within the meaning of Article .6 of Framework Decision 2002/584/JHA.

The Irish Supreme Court and the Irish High Court have decided to suspend the cases and address the Court of Justice with a set of 5 preliminary questions regarding the participation in prosecution of criminal justice, their independence and objectivity, respectively whether the German Prosecutor's Office is a judicial authority within the meaning of Article 6 (1) of Framework Decision 2002/584/JHA.

The CJEU has shown that the principle of mutual trust between Member States and the principle of mutual recognition have a fundamental importance in Union law as they allow the creation and maintenance of an area without internal frontiers ${ }^{34}$. The principle of mutual recognition applies to Article 1 paragraph 2 of the Framework Decision, which enshrines the rule that Member States are obliged to execute any European arrest warrant on the basis of this principle.

The arrest warrant constitutes a judicial decision within the meaning of Article 1 (1) of the Framework Decision, which requires it to be issued by a judicial authority, as the Court pointed out in its previous case-law ${ }^{35}$.

In the Ozcelik case ${ }^{36}$, the Court held that the public ministry's confirmation of a national arrest warrant issued by the police, which is the basis of the European arrest warrant,

\footnotetext{
${ }^{30}$ CJEU: dec. of 27 May 2019, OG and PI C-508/18 and 82/19 PPU, EU: C: 2019, parag. 90.

${ }^{31}$ Article 33 of the Irish Law of 2003 on the European Arrest Warrant.

${ }^{32}$ Art.146 of the German Judicial Organization Act.

${ }^{33}$ Art. 147 of the German Judicial Organization Act.

${ }^{34}$ See paragraph 43 of the preliminary ruling.

${ }^{35}$ CJUE: dec. of 10 November 2016, Poltorak C-452/16 PPU, EU: C: 2016: 858; dec. of 10 November 2016, Kovalkovas, C477/16 PPU, EU: C: 2016: 861.
} 


\section{Mihaela Pătrăuş}

falls within the notion of "judicial decision" and its existence or mandate of national arrest must be indicated in the European Arrest Warrant form, in accordance with the provisions of Article 8, paragraph 1, letter c of Framework Decision 2002/584/JHA.

Under the principle of procedural autonomy, Member States may designate the competent judicial authority to issue a European arrest warrant, but the meaning and scope of these notions can not be left to the discretion of each Member State.

The Court has held that this concept requires an autonomous and uniform interpretation in the European area, requiring it to be determined by reference to the terms of Article 6 (1) of the Framework Decision, the context in which it forms part, and the objective pursued by the Framework Decision.

At the same time, the Court underlined that one of the objectives of Framework Decision 2002/584/JHA is to ensure a system of free movement of judicial decisions in criminal matters, those prior to sentencing sentences and final sentences in an area of freedom, security and justice.

Therefore, to the extent that the European Arrest Warrant facilitates the free movement of prior and subsequent judicial decisions, it must be considered that the authorities which under national law are competent to adopt such decisions may fall within the scope of the Framework Decision.

An authority, such as the Prosecutor's Office, which has the power to prosecute a suspected person who has committed an offense for the purpose of bringing it before a court, is involved in the administration of justice in a Member State, is Germany.

Regarding the independence of the courts, the referring courts in Ireland have shown that they have serious doubts that the German Prosecutor's Office, which belongs to a hierarchical structure, depending on the Minister of Justice, fulfills this condition.

When a European Arrest Warrant is issued for the purpose of arresting and surrendering the person prosecuted to another Member State for the purpose of prosecution, it must have received procedural guarantees and fundamental rights protected by the judicial authority of the issuing Member State ${ }^{37}$.

The European Arrest Warrant system includes a two-level protection of the procedural rights and fundamental rights to be enjoyed by the intended person. Issuing a European arrest warrant is likely to impair the right of freedom of the requested person under Article 6 of the CDFU and the protection implies the adoption, at least at one of the two levels, of a decision that meets the requirements inherent in judicial protection effective.

If the law of the issuing Member State attributes the power to issue a European arrest warrant to an authority which, although participating in the administration of justice, is not a judge or a court, the national judicial decision on the arrest warrant on which the European arrest warrant is based must to meet such requirements. It ensures that the decision to issue a European arrest warrant for the purposes of prosecution is based on a national procedure subject to judicial review and the person sought has been granted guarantees against arbitrariness or unjustified deprivation of liberty.

Consequently, the Court concluded that the "issuing judicial authority" as referred to in Article 6 (1) of the Framework Decision is the entity that performs this function objectively, independently without being exposed to the risk that its power of decision would be the subject of external orders or instructions, in particular from the executive branch, and the authority which takes the decision to issue the European arrest warrant has the task of ensuring a second level of protection, even when that mandate European arrest warrant is based on a national decision pronounced by a judge or a court.

The Court stressed that although the decision of the German Prosecutor's Offices to issue a European Arrest Warrant may be the subject of an appeal by the person pursued in the competent courts, given that a possible individual instruction is allowed to the Minister of

\footnotetext{
${ }^{36}$ CJUE, dec. of 10 November 2016, Ozcelik C-453/16 PPU, EU: C: 2016: 861.

${ }^{37}$ CJUE, dec. of 1 June 2016, Bob-Dogi, C-241/15, EU: C.2016: 385, point 56.
} 


\section{BRIEF COMMENTS ON THE CONCEPT OF JUDICIAL AUTHORITY JURISDICTION \\ UNDER ARTICLE 6 OF COUNCIL FRAMEWORK DECISION NO. 2002/584/JHA \\ REGARDING THE EUROPEAN ARREST WARRANT}

Justice on the occasion of the issue of the European arrest warrant these prosecutors are at risk of being influenced by the executive power and therefore do not appear to fulfill one of the requirements imposed to qualify as an issuing judicial authority within the meaning of Art. 6 paragraph 1 of the Framework Decision.

\section{CONCLUSIONS}

CJEU in interpreting the notion of "issuing judicial authority" within the meaning of Art. 6 paragraph 1 of Framework Decision 2002/584 / JHA, as amended by Council Framework Decision 2009/200/JHA of 26 February 2009, examining whether the Public Prosecutor may be the issuing judicial authority of the European Arrest Warrant, took into account inter alia the following essential elements:

- participation in the administration of criminal justice ${ }^{38}$ (the prosecutor has the power to prosecute a suspected person who has committed an offense in order to bring it before a court and/or has a key role in the conduct of criminal proceedings and/or has the power to order the referral);

- the objectivity ${ }^{39}$ (the national status of the prosecutor must establish objectivity in the execution of the criminal instruction, that is, it takes into account all incriminating and decriminalizing elements);

- independence ${ }^{40}$ (the legal position of the prosecutor in the national legal order must give him guarantees of independence from the executive power, without the risk of being subjected to an individual instruction from the executive power);

- the appeal ${ }^{41}$ (the prosecutor's decision to issue the European arrest warrant must be the subject of an appeal that meets the requirements inherent in effective judicial protection).

If, by its previous case-law, the Luxembourg Court had exhaustively interpreted the notion of judicial authority, including the authorities involved in the administration of criminal justice in the Member States, without ministries or police services, which are part of the executive power, by that judgment, makes a similar interpretation to that of the Strasbourg Court, pointing out that the judicial authorities issuing a European arrest warrant must provide institutional and judicial safeguards for criminal proceedings to any person arrested or detained in full compliance with fundamental human rights.

The effects of this decision are binding all Member States and require clarification from 17 Member States on the nature of the European Arrest Warrant Authority, even a possible intervention by the law of these EU Member States, for the application of EU law and the interpretation of normative acts in line with the CJEU case law, in order to facilitate the settlement of arrest warrant cases in full compliance with the principles of mutual recognition and mutual trust in judgments in the European area.

\section{BIBLIOGRAPHY}

V.Berger, Jurisprudence de la Cour européenne des Droits de l'Homme, Sirey, Paris, 5-e, 1996;

G.Stefani, G.Levasseur and B.Bouloc, Criminal Procedure, 17-e, Ed.Dalloz, Paris, 2000;

S. Guinchard, M. Bandrac, X. Lagarde and M. Douchy, Droit processuel. Droit commun et droit compara du process, 2-e, Ed. Dalloz, Paris, 2003;

I.Gâlea, Treaty of the European Union. Comments and Explanations, Ed. C.H.Beck, Bucharest, 2012;

\footnotetext{
${ }^{38}$ See paragraphs 29-42 and 50-63 of the dec. of May 27, 2019, GO and PI C-508/18 and 82/19 PPU, EU: C: 2019.

${ }^{39}$ See paragraphs 51, 73 of the dec. of May 27, 2019, GO and PI C-508/18 and 82/19 PPU, EU: C: 2019.

${ }^{40}$ See paragraphs 51-52, 73-74 of the dec. of May 27, 2019, GO and PI C-508/18 and 82/19 PPU, EU: C: 2019.

${ }^{41}$ See paragraphs 53, 75 of the dec. of May 27, 2019, GO and PI C-508/18 and 82/19 PPU, EU: C: 2019.
} 


\section{Mihaela Pătrăuş}

Gh.Mateuţ, Criminal Procedure Treaty. The general part. Volume I, Ed. H. Beck, Bucharest, 2007;

D.Bogdan, Preventive Arrest and Detention in ECHR Case Law, Ed. Hamangiu, Bucharest, 2008;

P.Craig and G.Burca, European Union Law - comments, jurisprudence and doctrine, 4th edition, Hamangiu Publishing House, Bucharest, 2009;

M. Patraus, European Institutional Law. University Course, Ed. Pro Universitaria, Bucharest, 2018;

M. Pătrăuş, Reflections on Criminal Law Issues, as provided by Article 5 of the European Convention on Human Rights, in the volume of Studies on ECHR jurisprudence, National Institute of Magistracy, Bucharest, 2003;

Commission Communication, Manual on the Issuance and Enforcement of a European Arrest Warrant in OJ C 335/01 of 6 October 2017;

ECHR jurisprudence;

CJEU jurisprudence. 